DOI: $10.22616 /$ REEP.2020.054

\title{
Teacher's Prestige in Contemporary Czech Society
}

\author{
Katerina Tomsikova ${ }^{1}$ Ing.; Karel Tomsik ${ }^{2}$ Ing., PhD; Karel Nemejc ${ }^{3}$ Ing., PhD \\ Czech University of Life Sciences Prague, Faculty of Economics and Management \\ Institute of Education and Communication, Czech Republic \\ tomsikova@ivp.czu.cz'; tomsik@pef.czu.cz²; nemejc@ivp.czu.cz ${ }^{3}$
}

\begin{abstract}
Since the last third of the 20th century, schools have been losing their exclusive position of a place of acquiring education. However, education is much more beneficial for current, so called "knowledge society", if we are able to enforce it. Educational system in the Czech Republic (CZ) has undergone essential transformation during last 15 years; a significant decentralization has occurred in regional education. The current aim following the Strategy Europe 2020 is to improve results and motivation of pupils and students at all levels of the educational system; an accent is given also to development of education based on lifelong learning conception. The article is dealing with the problematics of teacher's prestige. The results show that one of possible reasons for lowering teachers' prestige may be their low remuneration. In this respect, could improve the current situation as well in financing schools according to number of students and hours taught since 2020. Another reason is lower respect of teachers by students and their parents. The state should actively solve the situation by implementing rules to protect the school and teachers from the negative behaviour of students. Personality of the teacher will remain an equally important aspect.
\end{abstract}

Keywords: education, knowledge society, regional education, prestige of teachers.

\section{Introduction}

Since the last third of the 20th century, school has ceased to serve as an exclusive place for acquiring education as society also shares education through media and the Internet. However, education is the more useful for the contemporary society - referred to as "knowledge society" - the more it is made use of. The first reflections on the knowledge society were formulated by American sociologist Robert R.E. Lane (1966), who claimed that, as a result of a general expansion of education, pure science, along with technical knowledge, would soon supersede all ideological prejudices and political stereotypes and would become part of people's everyday life. To describe such society, R.E. Lane coined the term "knowledgeable society". D. Bell (1975) used the term "industrial society", referring to a society in which knowledge becomes a central productive factor, a critical source for creation of values, and a major drive of economic growth. D. Bell considered in particular theoretical knowledge to be a fundamental axis of the development of technology and economic growth. However, knowledge is more than information. Knowledge makes it possible not only to filter data that have information value from a large pool of data. Knowledge is a comprehensive from of how we explore the world - its recognition, understanding, comprehension (Liessmann, 2006, 23). First, education was understood as a programme of self-education of people, formation and development of body, spirit, and soul, talent and gift that should lead people to the development of individuality and confident participation in the life of the community and its culture (Liessmann, 2006, 39).

The last quarter of the 20th century saw major shifts in social and economic contexts in which education is to be applied. However, the current practice still focuses on utility - for the individual, for the economy, for society. This is legitimate in certain areas, and no system of education can be blamed for striving for this kind of utility. But if education is reduced only to that which is useful, if only that which can be utilized receives funding, if everything is viewed from the perspective of usability, young people in schools and universities have no chance to get acquainted with things just for their own sake, to be fascinated by an object, to curiously pose questions even when no answers follow or they cannot be used in their careers (Liessmann, 2014, 132). In this perspective, an important role of the teacher must be taken into account. There are many factors influencing teacher's quality and hence his or her prestige. If work-life balance is in the conflict state and the teacher is not satisfied with his work, the educational institution may suffer adverse consequences (Gedviliene, Didziuliene, 2019, 262). On the other hand, some findings stress the necessity to systematically upgrade teacher's knowledge and understanding of the subject area 
(Muzafarova, 2019, 281). B. Holmes (Holmes, 2003, 192) raises a question concerning the nature of teacher's basic function. Should he or she be the conserver of the tradition and mediator between one generation and the next or a dynamic element in a changing society? Regardless of which approach the teacher prefers, his or her prestige is shaped in a different way. According to $\mathrm{H}$. Domanski, prestige is allocated to other people for their intelligence, knowledge and good looks, social roles they fulfil, occupational positions they take and life achievements they attain (Domanski, 2015, 11).

\section{Current changes in education and the system of education in the Czech Republic}

In the past 15 years, the institutional anchoring of the school system has undergone a radical transformation. Regional education has experienced a major decentralization, consisting in the transfer of competences from the central level of state administration to the level of regional and municipal administration. The introduction of a two-tier curriculum was yet another change; it replaced instruction based on previously used teaching documents with a more flexible instruction based on School Educational Programmes, which each school devised on the basis of the Framework Educational Programme (hereinafter referred to as "FEP"). Since 2011, the Czech Republic has implemented a state school-leaving examination and, since 2015, a unified apprenticeship examination. In the 1990s, secondary schools and vocational schools faced a steep decline in the number of students. Regional authorities carried out a so-called optimization of the network of secondary schools in the Czech Republic. The process continued at different rates in individual regions and it is currently being evaluated.

The year 2019 is the fifth year of the implementation of the Strategy for Education Policy of the Czech Republic until 2020 (hereinafter referred to as the "CZ Education Strategy"). It is based on the main economic reform agenda of the European Union the Europe 2020 Strategy, which replaced the Lisbon Strategy. Following an assessment of the state of the education system in the Czech Republic, the CZ Education Strategy stipulated three key priorities, namely reducing inequalities in education, supporting quality teacher education, and responsible and efficient management of the education system (Strategy for Education Policy..., 2019, 3).

The implementation documents of the CZ Education Strategy also include the Long-Term Plan of Education and Development of the CZ Education System 2015-2020 (hereinafter referred to as the "Long-Term Plan"). It aims to further improve the quality of vocational education and puts emphasis on the intensification of cooperation between schools, employers and branches of the Labour Office. One of the ways to improve the position of graduates on the labour market could be a systematic linking of FEP to the National Register of Qualifications, which reflects current as well as prospective requirements of employers. The Long-Term Plan also includes a chapter called "Education for Sustainable Development" (Dlouhodobý záměr vzdělávání..., 2019, 12-13).

How much of a priority education is for different countries is reflected, among other things, in how much a given country spends on education as a percentage of GDP. According to the OECD annual survey, the results of which are published in Education at a Glance and which, using selected indicators, compare the education system in OECD countries, the Czech Republic spent $4.4 \%$ of GDP on education in 2012. The OECD average is $5.3 \%$ of GDP. In terms of total public spending on education, the OECD average is $11.6 \%$ of total public spending. The Czech Republic, which spends $8.9 \%$, is well below the OECD average. Regarding unemployment by educational attainment level, the Czech Republic has one of the lowest unemployment levels of tertiary-educated adults (2.6\%) among OECD countries, and it also has one of the biggest differences in unemployment between people with lower than secondary education $(20.7 \%)$ on the one hand and people with higher secondary and post-secondary non-tertiary education $(5.4 \%)$ or tertiary education $(2.6 \%)$ on the other hand (Education at a Glance, 2019, 18).

\section{Teacher's prestige}

The research entitled "Analysis of Prerequisites and Educational Needs of Educators for the Improvement of Their Work", conducted by the Ministry of Education, Youth and Sports (hereinafter referred to as "MSMT") in 2009 showed that also teachers believed that the prestige of their profession would increase if they were paid better (32\% of respondents), that it was MSMT, which should take responsibility for increasing of the prestige ( $25 \%$ ), and that the importance of the teaching profession should be supported by the media $(15 \%)$. On the other hand, the same number of teachers contacted for 
the research said that it was the teachers and teacher associations who should primarily be responsible for increasing the prestige of the teaching profession. The least number of teachers $(10 \%)$ believed that no special effort was needed to increase the prestige - every teacher has the prestige they deserve (Analýza předpokladů..., 2009). The fact that teachers mentioned low remuneration as the most important factor is in line with an OECD survey (Education at a Glance..., 2019, 34), which showed that in OECD countries, teachers in pre-primary and primary education receive $78 \%$ of the average salary of professionals with a similar level of education, in case of lower secondary education it is $80 \%$ and in case of upper secondary education it is $82 \%$. In the Czech Republic, teachers in primary and lower secondary education receive just $52 \%$ of the average salary of a professional with a similar level education, in case of upper secondary education it is $56 \%$.

The aim of the study is to compare opinions of our respondents on the position of teachers at primary schools and universities with those of public. Further, to clarify on what basis they asses the prestige of the teaching profession and what changes (for better or worse) they perceive at primary school and university teachers. For selected respondents, another aim was to find out their opinion on the position of a teacher at a secondary school. This topic has been researches also by M. Köller, M. Stuckert and J. Möller, who stated that "The prestige of the teaching profession in society influences the high school graduates' choice of education as a course of study and teachers' job satisfaction” (Köller, Stuckert, Möller, 2019, 1).

\section{Methodology}

The article draws on a longitudinal survey of the Public Opinion Research Centre, Institute of Sociology of the Czech Academy of Sciences (hereinafter referred to as "CVVM SOÚ AV ČR") entitled "Prestige of Occupation" conducted since 2004 and repeated in 2007, 2011, 2013, and 2016 (Prestiž povolání..., 2019). Its respondents were students of the 3 rd year of the field "Counselling in Vocational Training" in full-time form of study $(\mathrm{N}=33)$ and in part-time form of study $(\mathrm{N}=30)$, hereinafter referred to as "POV/K" $(\mathrm{N}=63)$. The survey was conducted in October 2019. As part of the CVVM SOÚ AV ČR survey, all respondents received a list of twenty-six professions from which they were asked to select the professions for which they had most respect, and award them points according to instructions. The most prestigious place (since 2004) has consistently been occupied by the profession of doctor of medicine, followed by scientists; since 2011, nurses have repeatedly placed third, teachers at university have placed fourth and teachers at primary schools have placed fifth. The respondents were supposed to answer four questions; students of the part-time form of study also commented on two other questions concerning the position of teachers at secondary school. This was because these students were older people who had more experience not only with education, but they also had own work experience and had been following the development in society for a longer period of time.

\section{Results and Discussion}

The following hypotheses were proposed:

- $\mathrm{H}_{1}$ : Students of POV/K will assess the position of teachers at primary schools and universities same as respondents in the survey.

- $\mathrm{H}_{2}$ : Prestige of teachers at primary schools and universities is affected by the fact that they educate pupils and students.

- $\mathrm{H}_{3}$ : According to students of POV/K, the position of teachers at secondary schools will be similar to that of teachers at primary schools and universities.

The first hypothesis was tested as the first step. Median values clearly show that students of POV/K chose the same position for teachers at university (position 4.) and primary school (position 5.) like the respondents of the CVVM SOÚ AV ČR survey. $\mathrm{H}_{1}$ was confirmed.

Next step was to find out which profession the POV/K students consider to be comparable to that of a teacher at a university and a primary school.

The Table 1 shows that respondents consider scientists to be a comparable profession to that of a teacher at university (because also teachers at university conduct research), followed by the profession of judge (because both professions have an impact on the lives of others and must be just). The profession of nurse 
is comparable to that of teacher at primary school (because both professions help and have responsibility) and police officer (because they provide people with basics for life, show how a person should behave).

Table 1

Professions comparable to that of teacher at university and primary school

\begin{tabular}{|c|c|c|c|c|}
\hline \multirow{2}{*}{ Place } & \multicolumn{4}{|c|}{ Opinions of students of POV/K } \\
\cline { 2 - 5 } & \multicolumn{4}{|c|}{ Professions comparable with the position of teachers } \\
\cline { 2 - 5 } & At university & Frequency in \% & At primary school & Frequency in \% \\
\hline $1^{\text {st }}$ & Scientist & 52 & Nurse & 14 \\
\hline $2^{\text {nd }}$ & Judge & 25 & Police officer & 16 \\
\hline $3^{\text {rd }}$ & Other & 23 & Teacher at university & 70 \\
\hline
\end{tabular}

In order to verify the second hypothesis, it was necessary to find out the circumstances that most affect the position of a teacher at a university (Table 2) and a primary school (Table 3 ).

Table 2

Circumstances that have the biggest impact on the position of teacher at university

\begin{tabular}{|l|l|c|}
\hline \multirow{2}{*}{ Place } & \multicolumn{1}{|c|}{ Opinions of students of POV/K } & \multicolumn{1}{|c|}{ Circumstances } \\
\cline { 2 - 3 } & \multicolumn{1}{|c|}{ Frequency in \% } \\
\hline $1^{\text {st }}$ & Has a university education & 24 \\
\hline $2^{\text {nd }}$ & Teaches future university graduates & 10 \\
\hline $3^{\text {rd }}-4^{\text {th }}$ & Has deep knowledge & 8 \\
\hline $3^{\text {rd }}-4^{\text {th }}$ & Has to further educate oneself & 8 \\
\hline $5^{\text {th }}$ & Conducts research and publishes results & 6 \\
\hline $6^{\text {th }}$ & Has a good salary & 5 \\
\hline $7^{\text {th }}$ & $\begin{array}{l}\text { Other (has practical knowledge and experience, prestige, must } \\
\text { be responsible, there is a shortage of such) }\end{array}$ & 39 \\
\hline
\end{tabular}

Respondents consider the fact that teachers at university have a university education, which they believe is prestigious in itself, the main factor that impacts their position. The second most important factor in their opinion is the fact that teachers at university teach other future university graduates. The fact that teachers at university have deep knowledge and have to further educate themselves is on the $3^{\text {rd }}$ and $4^{\text {th }}$ place, followed by the fact that teachers at university conduct research and publish results. Fife percent of respondents said that teachers at university have a good salary, which also increases their prestige.

Table 3

Circumstances that have the biggest impact on the position of teacher at primary school

\begin{tabular}{|c|c|c|}
\hline \multirow{2}{*}{ Place } & \multicolumn{2}{|l|}{ Opinions of students of POV/K } \\
\hline & Circumstances & Frequency in $\%$ \\
\hline $1^{\text {st }}$ & Educates, shapes the personality of a child & 22 \\
\hline $2^{\text {nd }}$ & Has a university education & 10 \\
\hline $3^{\text {rd }}-4^{\text {th }}$ & Educate, creates a basis for further education & 6 \\
\hline $3^{\text {rd }}-4^{\text {th }}$ & It is a psychologically demanding profession & 6 \\
\hline $5^{\text {th }}$ & $\begin{array}{l}\text { Other (helps the family of pupils in solving problems, has an individual } \\
\text { approach to pupils, it is a needed profession, has extracurricular activities) }\end{array}$ & 56 \\
\hline
\end{tabular}

According to the respondents, the most important factor affecting the position of teachers at primary school is that they educate and shape the personality of a child. In the second place they mentioned that it is important that teachers at primary school have a university education. It is only in the $3^{\text {rd }}-4^{\text {th }}$ place that students mention that teachers at primary school educate and create a basis for further education. $\mathrm{H}_{2}$ was not confirmed; for teachers at university their prestige is influenced by the fact that they have a university education, while for teachers at primary school it is the fact that they educate and shape the personality of a child. 
Furthermore, respondents were asked what had changed for the position of teacher at the university (Table 4) at the primary school (Table 5) for the better and worse.

Table 4

Changes in the position of teachers at university in time

\begin{tabular}{|c|l|c|c|l|c|}
\hline Place & \multicolumn{1}{|c|}{ Changes for the better } & $\begin{array}{c}\text { Frequency } \\
\text { in \% }\end{array}$ & Place & \multicolumn{1}{|c|}{ Changes for the worse } & $\begin{array}{c}\text { Frequency } \\
\text { in \% }\end{array}$ \\
\hline $1^{\text {st }}$ & $\begin{array}{l}\text { They have more possibilities } \\
\text { to cooperate, educate } \\
\text { themselves, and publish, also } \\
\text { on international level }\end{array}$ & 40 & $1^{\text {st }}$ & $\begin{array}{l}\text { Due to the increased number of } \\
\text { universities, primarily private } \\
\text { ones, the university degree lost } \\
\text { its prestige, students are weaker } \\
\text { and less motivated }\end{array}$ & 35 \\
\hline $2^{\text {nd }}$ & $\begin{array}{l}\text { They are not affected by any } \\
\text { ideology }\end{array}$ & 21 & $2^{\text {nd }}-3^{\text {rd }}$ & $\begin{array}{l}\text { Less personal approach to } \\
\text { students }\end{array}$ & 11 \\
\hline $3^{\text {rd }}$ & $\begin{array}{l}\text { They can use more modern, } \\
\text { better quality technologies } \\
\text { and resources }\end{array}$ & 17 & $4^{\text {th }}$ & Lower salaries & 11 \\
\hline \multirow{2}{*}{$4^{\text {th }}$} & $\begin{array}{l}\text { Other (prestigious } \\
\text { occupation, possibility of } \\
\text { self-realization) }\end{array}$ & 22 & $5^{\text {th }}$ & $\begin{array}{l}\text { Show indifference towards } \\
\text { students }\end{array}$ & 5 \\
\cline { 4 - 6 } & $6^{\text {th }}$ & $\begin{array}{l}\text { Other (population of teachers is } \\
\text { getting old, lower level of } \\
\text { students) }\end{array}$ & 38 \\
\hline
\end{tabular}

Respondents consider the possibility to cooperate, educate, and publish more, also on international level, as a change for the better regarding the position of teachers at university. In the second place they mentioned the fact that the instruction of teachers at university is no longer affected by any ideology, followed by the fact that teachers at university can use more modern, better quality technologies and resource. Students believe that due to the increased number of universities, primarily private ones, the university degree has lost its prestige, which they consider a change for the worse. They also note that teachers at university do not have a personal approach to students $(11 \%)$, or even show indifference ( $5 \%$ ). The 2nd-3rd position is occupied by the opinion that the position of teachers at university has changed for the worse because they have lower salaries.

Table 5

Changes in the position of teachers at primary school in time

\begin{tabular}{|l|l|c|l|c|}
\hline \multicolumn{1}{|c|}{ Place } & \multicolumn{1}{|c|}{ Changes for the better } & $\begin{array}{c}\text { Frequency } \\
\text { in \% }\end{array}$ & \multicolumn{1}{|c|}{ Changes for the worse } & $\begin{array}{c}\text { Frequency } \\
\text { in \% }\end{array}$ \\
\hline $1^{\text {st }}$ & $\begin{array}{l}\text { They can use more modern, quality } \\
\text { technologies, resources, and aids }\end{array}$ & 38 & $\begin{array}{l}\text { They enjoy less respect among } \\
\text { pupils and parents }\end{array}$ & 67 \\
\hline $2^{\text {nd }}$ & They are not affected by any ideology & 13 & $\begin{array}{l}\text { Problems with discipline of } \\
\text { children, worsened cooperation } \\
\text { with parents }\end{array}$ & 6 \\
\hline $3^{\text {rd }}$ & $\begin{array}{l}\text { They have better possibility to } \\
\text { influence the content of the lessons }\end{array}$ & 11 & Other (difficult to attract pupils, & 27 \\
\hline $4^{\text {th }}$ & Their salaries have risen & 8 & great administrative) & 27 \\
\hline $5^{\text {th }}$ & Other (education is more prestigious) & 30 & & \\
\hline
\end{tabular}

The Table 5 shows that respondents consider the possibility to use more modern and better-quality technologies and aids as a change for the better in the position of teachers at primary school. Another positive change, according to the students, is the fact that also teachers at primary school are no longer affected by any ideology, that they can have a greater influence on the content of the lessons, and that their salaries have risen. Respondents perceive (and in a significant percentage of cases) that the main change for the worse is less respect for teachers among pupils and parents.

Other questions of the questioning tool were designed only for students of the part-time form of study (hereinafter referred to as "POVK") who were older and more experienced. They were asked about the 
position of teachers at secondary school. In testing the third hypothesis, students were asked about the perceived position of teachers at a secondary school. In the majority of cases, POVK students put teachers at secondary school behind both teachers at university and teachers at primary school. $\mathrm{H}_{3}$ was confirmed.

In terms of demands on expertise, respondents put teachers at secondary school between teachers at university and teachers at secondary school. They stress that, unlike teachers at primary school, they teach older students, who are also more difficult. This is also reflected in the taught subject matter, which they must be able to explain very well, unlike teachers at university (Table 6).

Table 6

POVK students' opinions on the difference in demands on teachers at secondary school compared to teachers at primary school and at university

\begin{tabular}{|c|c|c|c|c|}
\hline Place & $\begin{array}{c}\text { Comparison with teachers at } \\
\text { primary school }\end{array}$ & $\begin{array}{l}\text { Frequency } \\
\quad \text { in } \%\end{array}$ & $\begin{array}{c}\text { Comparison with teachers at } \\
\text { university }\end{array}$ & $\begin{array}{l}\text { Frequency } \\
\quad \text { in } \%\end{array}$ \\
\hline $1^{\mathrm{st}}$ & Higher demands on expertise & 40 & Lower demands on expertise & 37 \\
\hline $2^{\text {nd }}$ & $\begin{array}{l}\text { They teach older students, who are } \\
\text { also more difficult }\end{array}$ & 20 & $\begin{array}{l}\text { They have to explain the } \\
\text { subject matter so that students } \\
\text { are able to understand it }\end{array}$ & 23 \\
\hline $3^{\text {rd }}$ & $\begin{array}{l}\text { Other (greater prestige than a } \\
\text { primary school teacher, must } \\
\text { constantly update its knowledge, } \\
\text { must be more specialized) }\end{array}$ & 40 & $\begin{array}{l}\text { They are not required to do } \\
\text { scientific work and publish } \\
\text { results }\end{array}$ & 17 \\
\hline $4^{\text {th }}$ & -- & -- & $\begin{array}{l}\text { They have to deal with } \\
\text { problems with discipline }\end{array}$ & 17 \\
\hline $5^{\text {th }}$ & -- & -- & Other & 6 \\
\hline
\end{tabular}

The paper presents results of a quantitative questionnaire approach. It will be followed by a qualitative approach and a relevant interviewing technique - semi-structured interviews with the management of selected secondary vocational schools with which IEC closely cooperates. The views of school directors on the teachers' prestige and the changes that should occurred will be analysed. The questionnaire survey will be used again in the next phase; the teachers of selected secondary schools will answer questions concerning the prestige of their profession.

Since 1989, the education system in the Czech Republic has undergone a number of changes and reforms. However, it is necessary to handle each change in a responsible manner, as the consequences in this area will be registered only after a certain time. In order for teachers to adopt further reforms, it is necessary that they should be provided with motivating, good quality, professional support in order to bring change in their work. Similar needs have also been defined in Slovakia. T. Zat'ková and M. Ambrozy point out that the Slovak education system is still substantially based on the Czechoslovak system as established by a fundamental reform from the 1970s (Zat'ková, Ambrozy, 2019, 249). Changes in teaching methods and introduction of new topics will be better implemented in such schools where students are highly motivated, with a real interest in education.

There is evident that the prestige of a teacher is affected not only by above described reasons but is a result of many other factors. R. Baltusite and I. Katane comes to conclusion that a modern teacher's career is characterized by self-development not only regarding professional aspects, but also concerning self-perception and self-cognition, which is a basis for the broadening of awareness (including professional awareness) (Baltusite, Katane, 2017, 37). J.L. Berger and Y. D'Ascoli come to conclusion that intrinsic value of the career and perceived teaching ability are among the most important motivations to teach (Berger, D'Ascoli, 2012, 247). Finally, the perception of the teaching profession by the society must also be considered, as mentioned e.g. by L. Paula and I. Priževoite (2019). 


\section{Conclusions}

The results of hypotheses testing were as follows:

- $\mathrm{H}_{1}$ was confirmed. Students of POV/K will assess the position of teachers at primary schools and universities same as respondents in the survey.

- $\mathrm{H}_{2}$ was not confirmed. Prestige of teachers at primary schools and universities is not affected by the fact that they educate pupils and students.

- $\mathrm{H}_{3}$ was confirmed. According to students of POV/K, the position of teachers at secondary schools will be similar to that of teachers at primary schools and universities.

Based on the findings, for both respondents and teachers, low salaries are considered one of the main reasons why teachers' prestige has been in decline. The replacement of the existing system of funding of schools through national directions, which stipulate the average amount of costs per unit of performance, i.e. per pupil, could initiate a positive change. The existing system of funding does not take into account the differences in the level of education, as it favours schools with more students. This forces schools to accept pupils who have neither the prerequisites nor the motivation to study just in order to secure sufficient financial resources for their operation. The change in funding would mean that schools would receive money in accordance with the number of lessons taught that are required by the given educational programme. It will be implemented from January 2020. Consequently, headmasters will not be forced to persuade pupils who are not interested in the study to stay at their schools, which should lead to an increase in both quality of schools and their prestige.

In the results of our survey, the most frequently mentioned change for the worse in case of teachers at primary school is the decreasing respect they have among pupils and parents. Here, the personality of the teacher will play the most important role and whether they are able to appeal to pupils and students, treat them as partners, without undermining their role as teachers, without pandering to them. Also, the family is responsible for the behaviour of children. The government should look for a mechanism that would protect both school and teachers against the bad behaviour of individual pupils.

Each government should strive to make sure that the following words by K.P. Liessmann do not come true: "No one knows what education means anymore, but everyone is demanding its reform."

\section{Bibliography}

1. Analýza předpokladů a vzdělávacích potřeb pedagogických pracovníků pro zkvalitňování jejich práce 2009 [Analysis of Prerequisites and Educational Needs of Pedagogical Staff to Improve Their Work 2009]. (2009). Ministerstvo školství, mládeže a tělovýchovy ČR Retrieved from http://www.msmt.cz/uploads/VKav_200/Analyza_191109/ZZ_ucitele_final.pdf (in Czech)

2. Baltusite R., Katane I. (2017). The Modern Teacher's Career. In V. Dislere (Ed.), The Proceedings of the International Scientific Conference Rural Environment. Education. Personality (REEP), 10. Jelgava: LLU, 30-39. Retrieved from https://lufb.llu.lv/conference/REEP/2017/Latvia-UnivAgricult-REEP-2017_proceedings-30-39.pdf

3. Bell D. (1975). The Coming of Post-Industrial Society: A Venture in Social Forecasting. New York: Basic Books.

4. Berger J.L., D’Ascoli Y. (2012). Motivations to Become Vocational Education and Training Educators: A Person-Oriented Approach. Vocations and Learning, 5(3), 225-249. doi: $10.1007 / \mathrm{s} 12186-012-9075-\mathrm{z}$

5. Dlouhodobý záměr vzdělávání a rozvoje vzdělávaci soustavy České republiky na období 2015 2020 [Long-term Plan for Education and the Development of the Education System of the Czech Republic for 2015-2020]. (2019). Retrieved from http://www.msmt.cz/vzdelavani/skolstvi-vcr/dlouhodoby-zamer-vzdelavani-a-rozvoje-vzdelavaci-soustavy-3 (in Czech)

6. Domanski H. (2015). Prestige. Frankfurt am Main: Peter Lang Edition.

7. Education at a Glance 2017: OECD Indicators. OECD. (2019). Paris: OECD Publishing. doi: 10.1787/eag-2017-en

8. Gedviliene G., Didziuliene R. (2019). Teachers' Job Satisfaction and Personal Life Balance Aspects. In V. Dislere (Ed.), The Proceedings of the International Conference Rural Environment. Education. 
Personality (REEP), 12. Jelgava: Latvia University of Life Sciences and Technologies, 256-262. doi: 10.22616/REEP.2019.033

9. Holmes B. (2003). Problems in Education: A Comparative Approach. London: Routledge \& Kegan Paul.

10. Köller M., Stuckert M., Möller J. (2019). Das Lehrerbild in den Printmedien: Keine „Faulen Säcke" mehr! [The image of the teaching profession in the print media: No longer "lazy slobs"!], Zeitschrift fur Erziehungswissenschaft, 22(2), 373-387. doi: 10.1007/s11618-018-0856-5 (in German)

11. Lane R.E. (1966). The Decline of politics and ideology in a knowledgable society. American Sociological Review, 31(5), 649-662. doi: 10.2307/2091856

12. Liessmann K.P. (2014). Geisterstunde: Die Praxis der Unbildung: Eine Streitschrift [Ghost hour: the practice of uneducation: a pamphlet]. Wien: Paul Zsolnay Verlag. (in German)

13. Liessmann K P. (2006). Theorie der Unbildung: Die Irrtümer der Wissensgesellschaft [Theory of Education: The Errors of the Knowledge Society]. Wien: Paul Zsolnay Verlag. (in German)

14. Muzafarova T. (2019). Planning Teachers' Professional Development. In V. Dislere (Ed.), The Proceedings of the International Conference. Rural Environment. Education. Personality (REEP), 12. Jelgava: Latvia University of Life Sciences and Technologies, 279-282. doi: 10.22616/REEP.2019.036

15. Paula L., Priževoite I. (2019). The status of the teaching profession in Latvia: Views of the teachers. Problems of Education in the 21 st Century, 77(1), 126-141. doi: 10.33225/pec/19.77.126

16. Prestiž povolání - únor 2016 [Profession prestige - February 2016]. (2019). Centrum pro výzkum veřejného minění. Retrieved from

https://cvvm.soc.cas.cz/media/com_form2content/documents/c2/a2025/f9/eu160309.pdf (in Czech)

17. Strategy for Education Policy of the Czech Republic until 2020. (2019). Ministry of Education, Youth and Sports Retrieved from http://www.vzdelavani2020.cz/images_obsah/dokumenty/strategy_web_en.pdf

18. Zat'ková T.Š., Ambrozy M. (2019) VET Teacher Preparation in Slovakia and the New Professionals Entrepreneurship Trainers for VET, TEM Journal, 8(1), 248-254. doi: 10.18421/TEM81-35 